\title{
Autonomy Learning in The Praxis of Language Education: A Systematic Review
}

\author{
Rina Husnaini Febriyanti \\ Universitas Indraprasta PGRI \\ *) Correspondence author: Jl. Nangka Raya No.58 C, Jakarta Selatan, DKI Jakarta 12530, Indonesia; \\ e-mail: rhfebriyanti@gmail.com
}

\begin{abstract}
The rapid increase of technology has transformed the praxis of language education and linked to the construct of autonomy learning. It is believed that the great technology accommodated the language learners to achieve their goals and aims. However, this statement is still debatable in language instruction. Given the previous consideration, the purpose of this study was to explore by reviewing 23 articles focusing on the autonomy learning issues that scholars or researchers discussed in their papers. The used research method in this manuscript was a systematic review. This study investigated six prior subheadings: the change number varies by year, the foci and purposes, countries where the articles were published, the applied research methods and data collection tools, the occupied sample group, sample size, and the adopted method theoretical frameworks and dimensions. The data collection was taken by categorizing the six subheadings and analyzing them by presenting bar graphics, figure maps, and tables. The study revealed various insights related to autonomy learning, such as still in the recent trending issue, applicable in multiple approaches, potentially in the sundry of theoretical frameworks, elaborating in numerous dimensions, with ample applied research methods, and so forth. In addition, the implication of this study considerably can be useful for the freshmen or sophomore researchers to gain state of the art or novelty before conducting research or publishing papers specifically on the topic of autonomy learning in the praxis of language education.
\end{abstract}

Keywords: Autonomy Learning; Language Education; Systematic Review

Article History: Received: 17/09/2021; Revised: 05/11/2021; Accepted: 04/12/2021; Published: 30/12/2021

How to Cite (MLA 7 ${ }^{\text {th }}$ ): Husnaini Febriyanti, Rina. "Autonomy Learning in The Praxis of Language Education: A Systematic Review." Hortatori Jurnal Pendidikan Bahasa dan Sastra Indonesia 5.2 (2021): 155-165. Print/Online. Copyrights Holder: Rina Husnaini Febriyanti. First Publication: Hortatori Jurnal Pendidikan Bahasa dan Sastra Indonesia (2017).

This work is licensed under a Creative Commons Attribution-ShareAlike 4.0 International License.

\section{Introductions}

The rapid growth of technology today has deployed to all sectors including in the education field. The transformation in the language teaching praxis has also changed in the instructional design, such as in the online/hybrid/blended context. This environment has encouraged not only the instructors but also the learners to do some adoptions and adaptions. These circumstances may lead an autonomy learning (AL) construct to be a concern because, simultaneously, the instructors and the learners should deliver or learn the materials and the technology features. In their study, Yang \& Kuo (14) revealed the students' learner autonomy as much as they enjoyed engaging in cross-cultural communication. They realized they had to be well-prepared before going online to hold a comprehensive conversation with their foreign teachers. A significant number of the students (over 95\%) noted they had to prepare in advance for their online discussion with their online teachers. The majority of the students enjoyed the online conversations with foreign teachers, and they reported their improvement in English as Foreign Language (EFL) reading, listening, and speaking. Although technology accommodates many elements in AL, it is possible to access language learning resources or offer learners options today. However, in practice, successful use of technology has proven to require a degree of autonomy. Evidence that much technology-mediated learning 
without direct teacher support is limited in scope and quality (Reinders 1). Therefore, the investigation of AL needs to be explored deeper.

Benson (23) defines in the context of language acquisition autonomy involved 'an ability to operate independently with the language and use it to communicate personal meanings in real, unpredictable situations' (autonomy as a communicator). In the context of classroom organization, it involved learners' 'ability to take responsibility for their learning and to apply active, personally relevant strategies' ('autonomy as a learner'). And in a broader context, it involved 'a higher-level goal of greater generalized autonomy as individuals' ('autonomy as a person). Meanwhile, Şenbayrak et al. (2) described several issues related to learners' beliefs and experience that determine the degree to which learners are ready for autonomous language learning: learners' decision-making abilities, beliefs about their own, and teacher's roles, motivation, and metacognitive strategy use. In addition, Little (1) argued 'language learner autonomy' denotes a teaching/learning dynamic in which learners plan, implement, monitor, and evaluate their learning. In the same line, Moradi (1) asserted that providing a framework for interconnections between autonomy, agency, and identity results in a better understanding of the challenges in EFL education. At the same time, the warnings could help overcome potential difficulties and barriers that may arise during research and teaching-learning processes. As an enticing proverb that rhymed by Lao $\mathrm{Zi}$ as cited by (Teng 2) "Give a man a fish, and you feed him for a day. Teach a man to fish, and you feed him for a lifetime." Based on the previous quote, an autonomous learner seems to be a learner who pursues knowledge out of curiosity and needs. Teng (4) added that a capacity to control learning also implies that learners need to make learning personally relevant. For example, learners will adjust their learning to align with needs and purposes that they have individually identified or have voluntarily agreed. The components of desire and freedom directly relate to learning something that has personal relevance. Moreover, learning management, cognitive processing, and learning content align learning a foreign language with individual needs and purposes.

Various discussions related to AL in the EFL context have been inquired in some studies. For instance, Peek (238) explored that learner autonomy with language learning locus of control in multilingual such as great motivation, persistence, knowing best learning, self-confidence, time-management, interaction quality, language classes, and material quality were positively enhanced a larger linguistic repertoire. In the distinct context, Wang et al. (18) revealed that blended learning demands a high level of learning autonomy, indicated $88.02 \%$ of the participants agreed that higher learning autonomy was very important for them to learn effectively in the blended learning environment. This result provides more evidence for the claim that blended learning provides learners with natural context and more opportunities to develop autonomous learning. On the other hand, Tseng et al. (25) suggested utilizing virtual environment programs for vocabulary learning. A student-centered practice should be adopted to promote learner autonomy. Training is administered before use to achieve efficiency in navigation and encourage interactivity with the program and with peers.

Moreover, for a better effect in long-term retention, pair work is recommended, especially in school contexts, to foster a supportive environment and nurture vocabulary growth through peer interaction. In the context of research methods, some review articles have been done previously by some scholars. For instance, Manzano Vázquez (3) delved into an exploratory review of teacher education autonomy by sorting papers from 1990-2015, yet he limited his study to focus on AL conceptual frameworks and strategies. Stockwell (42) described his review linking technology with learner motivation and autonomy, teacher psychology, and pedagogical considerations at a different point. Meanwhile, Lai (52) discussed current research on technology concerning learner autonomy, outlining major findings on the relationship between technology and learner autonomy in formal and informal learning contexts. Next, Lou (2) presented the perspective on autonomy in both LLA and SDT frameworks. In addition, Little (5) mainly focused on language learner autonomy, three pedagogical principles, and some theoretical reflections.

Notwithstanding, the revealing of AL in the EFL context has flourished and offered adequate impacts in achieving learning outcomes. Nevertheless, the excavation in the systematic review, particularly in the $\mathrm{AL}$, is still infrequent. Hence, the hallmarks of this current study are to present the systematic review of $\mathrm{AL}$, particularly in the EFL context, with the following research questions:

1. How does the number of AL articles vary by year?

2. What are the research foci and purpose of AL in the EFL context?

3. In which countries were the articles published?

4. Which research methods and data collection tools were utilized? 
5. Who constitutes the sample group and size occupied in the articles?

6. What are the theoretical frameworks and dimensions adopted in the articles?

\section{Method}

In the present study, the applied systematic review method was utilized in analyzing the findings. Twenty-three articles were analyzed in various categories through a systematic review (Altinpulluk and Kesim 3), specified the literature according to clarity, accuracy, and vivid steps. The reviewed papers were categorized and analyzed according to six research questions. During the data analysis, similar types of content were combined into the same category, and the redundant data to be eliminated were removed from the related category. The study used descriptive analysis that the findings were visualized with tables, graphics, and map figures.

The navigation journal publisher databases were selected from the "Social Sciences Citation Index (SSCI)" indexed in collecting the data. They were such as Taylor\& Francis (https://www.tandfonline.com), Wiley (https://onlinelibrary.wiley.com), Cambridge (https://www.cambridge.org/core), Elsevier (https://www.sciencedirect.com), and Sage (https://journals.sagepub.com). The obtained data were sorted by searching "Autonomy Learning" and "EFL" on the titles. These typed keywords were in quotation marks to ensure accurate obtained results. In the timespan section, the selection period was between 2015 and 2021, and only the preference of SSCI was indexed. Afterward, the further filtered list on the initial web page included only the research and review articles, which resulted in the required articles. Next, the analyzed articles' demographic was categorized by the journal's name, publisher, impact factor, quartile, and frequency. The impact factors and quartiles were sought from (https://www.scimagojr.com).

\section{Result and Discussions} 1):

The displaying published journals involved in the current systematic review are as follows (Table

Table 1. The Demographic of Analyzed Articles

\begin{tabular}{|c|c|c|c|c|}
\hline Journal & Publisher & $\begin{array}{c}\text { Impact Factor } \\
(\mathbf{2 0 2 0})\end{array}$ & Quartile & Frequency \\
\hline Innovation in Language Learning and Teaching & Taylor \& Francis Ltd. & 0.55 & Q1 & 3 \\
\hline Computer Assisted Language Learning & Taylor \& Francis Ltd. & 1.61 & Q1 & 2 \\
\hline Teaching in Higher Education & Taylor \& Francis Ltd. & 1.06 & Q1 & 1 \\
\hline Language Teaching Research & SAGE Publications Ltd. & 1.66 & Q1 & 3 \\
\hline Language Awareness & Taylor \& Francis Ltd. & 1.1 & Q1 & 1 \\
\hline Cogent Education & Taylor \& Francis Ltd. & 0.37 & Q3 & 3 \\
\hline Learning and Individual Differences & Elsevier BV. & 1.4 & Q1 & 1 \\
\hline International Journal of Electrical Engineering Education & SAGE Publications Ltd. & 0.29 & Q3 & 1 \\
\hline System & Elsevier B.V. & 1.42 & Q1 & 1 \\
\hline Annual Review of Applied Linguistics & Cambridge University Press & 1.87 & Q1 & 2 \\
\hline Interactive Learning Environments & Taylor \& Francis Ltd. & 0.92 & Q1 & 1 \\
\hline International Journal of Multilingualism & Taylor \& Francis Ltd. & 1.55 & Q1 & 1 \\
\hline TESOL Quarterly & Wiley-Blackwell & 1.74 & Q1 & 1 \\
\hline TESOL Journal & Wiley-Blackwell & 0.47 & Q1 & 1 \\
\hline Language Teaching & Cambridge University Press & 1.98 & Q1 & 1 \\
\hline Total & & & & 23 \\
\hline
\end{tabular}

\section{The Number of Autonomy Learning Articles Vary by Year}

Figure 1 displays eight SSCI-indexed articles published, which peaked in 2020 by attaching autonomy learning in their titles. However, the year 2018 and $2016(n=2)$ indicate an equally significant decline. Furthermore, an increasing number of articles were published in $2019(n=6)$ and are still in progress found in $2021(n=5)$. 


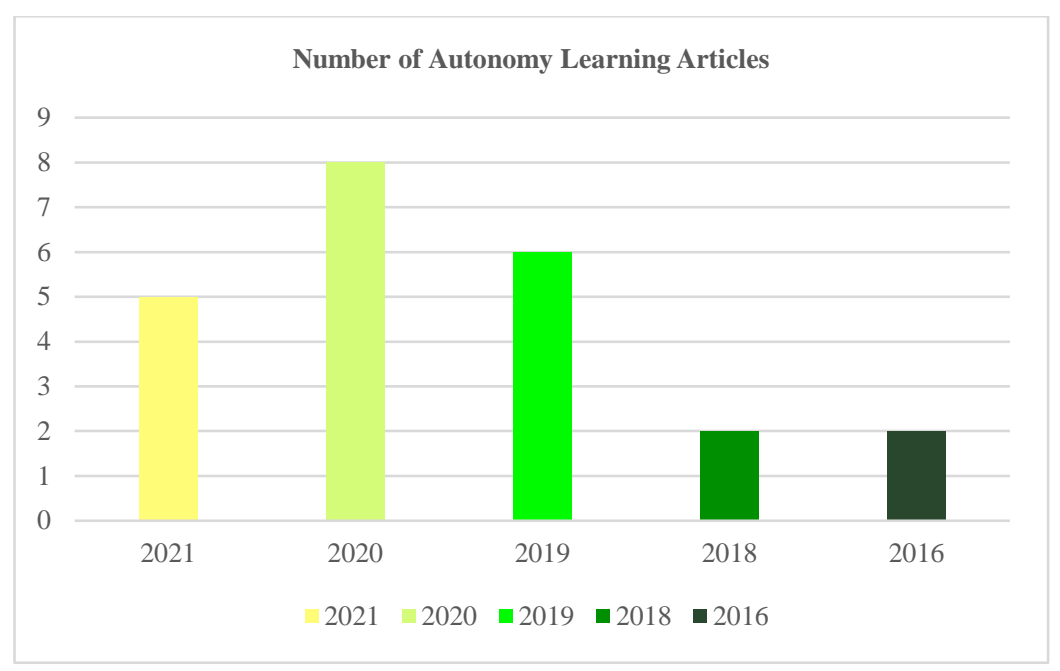

Graphic 1. The Number of Autonomy Learning Articles by Year

\section{The Research Foci and Purposes of Autonomy Learning in The EFL Context}

The following Table 2. presents research authors, foci, and purposes in the reviewed articles. In the research foci indicated autonomy learning with the various scopes in the dissimilar novel. They were such as individual and collaborative learning logs, integrating with massive open online courses (MOOCS), influence factors, autonomy freedom, the complexity of control shift, relationship and achievement, language mindsets, multilateral integration under multimedia, language learner autonomy, virtual environment, learner motivation and autonomy, teacher psychology, and pedagogical considerations, technology and learner autonomy, students' emotional intelligence and learner autonomy, teacher's perspective, learning autonomy in vocabulary, autonomy development, self-directed learning, language learning locus of control, complementary perspectives, teacher beliefs and practices, teacher development for autonomy, learners' readiness for autonomy and attitudes toward self-access centers, and promotion of learner autonomy. Meanwhile, for the research purposes, cover some constructs such as comparative, strategies, perceptions, relationships, effects, principles, development, conceptual, theoretical reflection, and theoretical review.

Table 2. The Research Foci and Purposes of Autonomy Learning in The EFL Context

\begin{tabular}{|c|c|c|}
\hline Author (s) & Research Foci (s) & Research Purpose (s) \\
\hline (Judy Shih) & Individual and Collaborative Learning Logs & Comparative Development \\
\hline (Ding and Shen) & $\begin{array}{l}\text { Integrating with Massive Open Online Courses } \\
\text { (MOOCs) }\end{array}$ & Learning Strategies \\
\hline (Basri) & Influence factors & Influence Factor Perceptions \\
\hline (Cirocki and Anam) & Autonomy Freedom & Perception and Improvement \\
\hline (Wang and Ryan) & The complexity of Control Shift & Teacher Perceptions of Control Shift \\
\hline (Ozer and Yukselir) & Relationship \& Achievement & $\begin{array}{l}\text { Relationship Between Learner Autonomy (LA), } \\
\text { Self-Directed Learning (SDL), Goal Commitment } \\
\text { (GC) \& Academic Achievement }\end{array}$ \\
\hline (Fadaee et al.) & Relationship & $\begin{array}{l}\text { Relationship between Autonomy, Second Language } \\
\text { Teaching Styles, \& Personality Traits }\end{array}$ \\
\hline (Zarrinabadi et al.) & Language Mindsets & $\begin{array}{l}\text { Learners' Perceptions of Their Teacher's } \\
\text { Autonomy Support Predict Their Language- } \\
\text { Mindsets }\end{array}$ \\
\hline (Xu et al.) & Multilateral Integrated Under Multimedia & $\begin{array}{l}\text { Comparison Traditional Learning, Traditional \& } \\
\text { Multimedia, And Multimedia Teaching }\end{array}$ \\
\hline (Borg and Alshumaimeri) & Language learner autonomy & Teachers' beliefs and practices \\
\hline (Tseng et al.) & Virtual Environment & $\begin{array}{l}\text { Effect integrating 3D on learner autonomy and } \\
\text { collaboration }\end{array}$ \\
\hline (Stockwell and Reinders) & $\begin{array}{l}\text { Motivation and Autonomy of The Learner, } \\
\text { Psychological Teacher, and Pedagogical Deliberation }\end{array}$ & $\begin{array}{l}\text { Pedagogical Principles for Using Technology in } \\
\text { The Classroom to Encourage Learner Motivation } \\
\text { and Autonomy }\end{array}$ \\
\hline (Lai) & Technology and Learner Autonomy & $\begin{array}{l}\text { Relation To Learner Autonomy Between } \\
\text { Technology \& Learner Autonomy in Formal \& } \\
\text { Informal Learning Contexts }\end{array}$ \\
\hline
\end{tabular}




\begin{tabular}{|c|c|c|}
\hline (Shabbani et al.) & Students' Emotional Intelligence \& Learner Autonomy & $\begin{array}{l}\text { Perceptions of learner autonomy: Interface between } \\
\text { social science and English language students }\end{array}$ \\
\hline (Almusharraf) & Teacher's Perspective; LA; Vocabulary & Teaching Practices and Agentive Roles \\
\hline (Yang) & Autonomy Development; Self-Directed Learning & $\begin{array}{l}\text { Students' Learner Autonomy in The Self-Directed } \\
\text { Learning Of ESP }\end{array}$ \\
\hline (Peek) & Language Learning Locus of Control & $\begin{array}{l}\text { Language Learning Locus of Control } \\
\text { Multilingualism }\end{array}$ \\
\hline (Lou et al.) & Complementary Perspectives & $\begin{array}{l}\text { Critical Conceptual Self-Determination and } \\
\text { Language Learner Autonomy Perspectives }\end{array}$ \\
\hline (Ahmadianzadeh et al.) & Teacher beliefs and practices & $\begin{array}{l}\text { Teacher beliefs and practices of LA in experience } \\
\text { and licensure }\end{array}$ \\
\hline (Manzano Vázquez) & Teacher Development for Autonomy & $\begin{array}{l}\text { The Development of Language Teacher Education } \\
\text { Initiatives for Teacher and Learner Autonomy }\end{array}$ \\
\hline (Şenbayrak et al.) & $\begin{array}{l}\text { Learners' Readiness for Autonomy and Attitudes } \\
\text { Toward Self-Access Centers }\end{array}$ & $\begin{array}{l}\text { Attitudes toward self-access centers (SACs) and } \\
\text { readiness for autonomous language learning }\end{array}$ \\
\hline (Little) & Language Learner autonomy & $\begin{array}{l}\text { Theoretical Reflections of Language Learner } \\
\text { Autonomy }\end{array}$ \\
\hline (Tsai) & Promotion of Learner Autonomy & $\begin{array}{l}\text { Perceptions and Perspectives LA with Flipped EFL } \\
\text { instructional model Framework }\end{array}$ \\
\hline
\end{tabular}

\section{Countries Publishing the Reviewed Articles}

Pointing to the countries where the articles are published (Figure 2), it is obvious that the highest number of articles were published in $\operatorname{Iran}(n=4)$, China $(n=4)$, and Taiwan $(n=4)$. The next country is Turkey $(n=3)$. The upcoming country is Saudi Arabia $(n=4)$. On the other lines, with a similar amount $(n=1)$, the other countries shown on the map are Canada, UK, Ireland, Spain, Japan, and Indonesia. However, some countries are not detected in the World Map. Hence, they were joined into the identified one, such as North Cyprus into Turkey and Hongkong into China. Apart from these, 16 articles were published in similar researchers' countries. Meanwhile, some researchers' articles $(n=7)$ were found from more than one country (international co-authors) included in a single article.

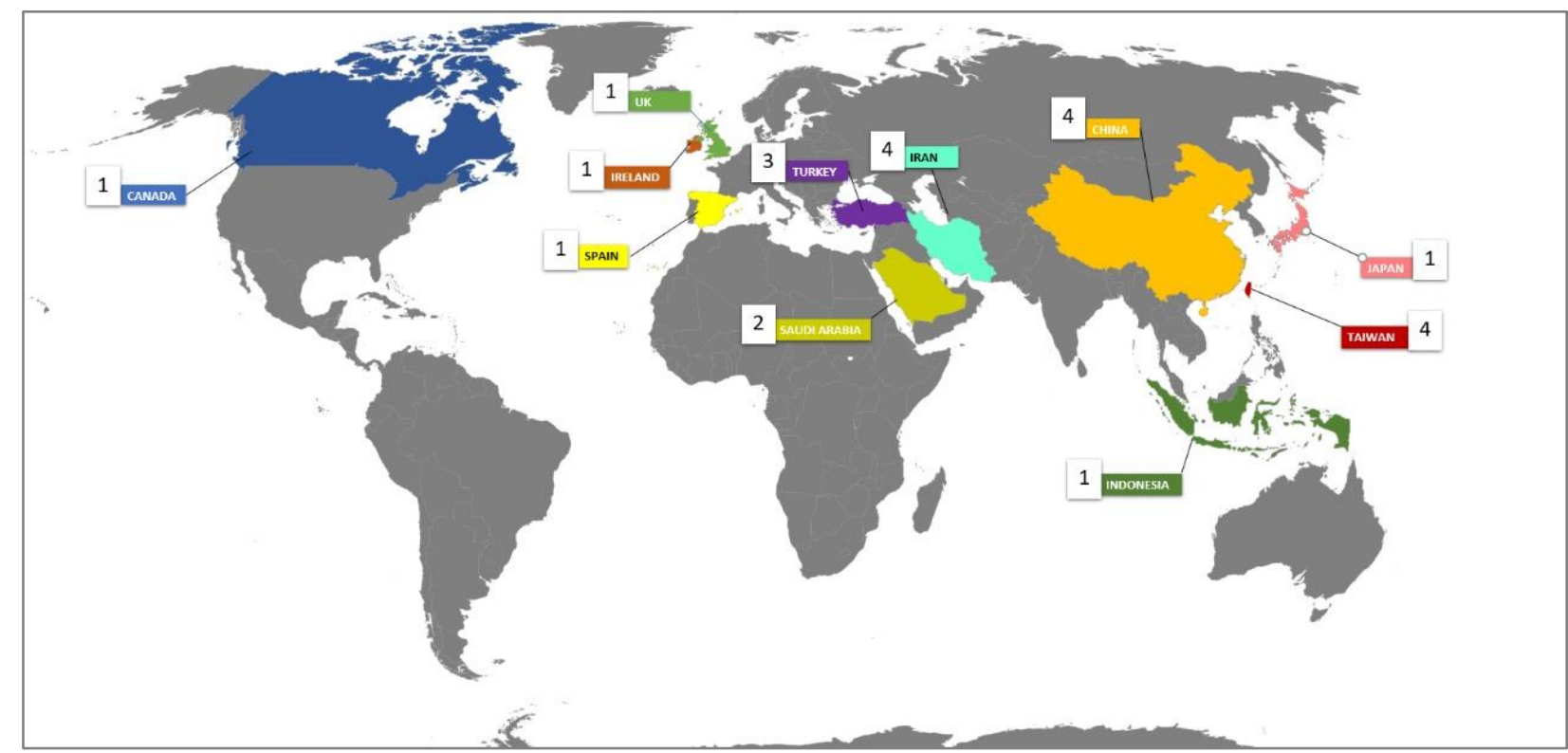

Note: Some countries are not detected in the World Map. Hence, they were joined into the identified North Cyprus: Turkey; Hongkong: China

Figure 1. Countries Publishing the Reviewed Articles

\section{The Applied Research Method and Data Collection Tools in the Reviewed Articles}

In the displaying of Table 3, the most preferred method is mixed $(n=7)$. The applied research method was quantitative $(n=6)$ in the not far amount while the qualitative approach was $(n=5)$. And for the review method number was $(n=5)$. In the same line, the employed data collection tools were varying. The highest data collection tool was a questionnaire $(n=12)$, and the next position was an interview $(n=11)$. There was also an observation as the tool $(n=2)$. Next, the used data collection tool was a test $(n=1)$. Meanwhile, there were also data collection tools with none because the type of research was a review article. In addition, some articles applied more than one data collection tool. 
Table 3. The Applied Research Method and Data Collection Tools in the Reviewed Articles

\begin{tabular}{lclc}
\hline \multicolumn{1}{c}{ Research Method } & Frequency & Data Collection Tool (s) & Frequency \\
\hline Qualitative & 5 & Interview & 11 \\
\hline Quantitative & 6 & Questionnaire & 12 \\
\hline Mixed & 7 & Observation & 2 \\
\hline Review & 5 & Test & 1 \\
\hline & & None & 5 \\
\hline Total & 23 & & 31 \\
\hline
\end{tabular}

*Note: Some articles applied more than one data collection tools

\section{The Occupied Sample Group and Size in The Reviewed Articles}

Table 4. exhibits dominantly of the sample group is the student $(n=11)$, and the next sample group is the teacher $(n=8)$. However, there was one article has two kinds of sample groups. For the instruction level, the majority was at the university level $(n=13)$. The other instruction levels were tertiary $(n=2)$, secondary $(n=2)$, and primary $(n=1)$. In the instruction learning context, the salient one was in the blended context $(n=7)$. The other contexts were online $(n=6)$ and offline $(n=2)$. There was also category "unspecified" $(n=3)$ because the research articles undeployed the learning contexts in detail. At the same time, for the sample sizes, there were various which the most size was in the range 1-100 $(n=7)$. The rest sizes were in the range 101-200 $(n=5), 201-300(n=2), 301-400(n=2), 701-800(n=1)$, and 801-900 $(n=1)$. In addition, sample group, instruction level, instruction context, and sample size "none" are indicated for the review articles.

Table 4. The Occupied Sample Group and Size in The Reviewed Articles

\begin{tabular}{|c|c|c|c|c|c|c|c|}
\hline Sample Group & $\mathbf{f}$ & Instruction Level & $\mathbf{f}$ & Instruction Context & $\mathbf{f}$ & Sample Size & $\mathbf{f}$ \\
\hline Student & 11 & University & 13 & Online & 6 & $1-100$ & 7 \\
\hline Teacher & 8 & Tertiary & 2 & Offline & 2 & $101-200$ & 5 \\
\hline \multirow[t]{5}{*}{ None } & 5 & Secondary & 2 & Blended & 7 & $201-300$ & 2 \\
\hline & & Primary & 1 & Unspecified & 3 & $301-400$ & 2 \\
\hline & & None & 5 & None & 5 & $701-800$ & 1 \\
\hline & & & & & & $801-900$ & 1 \\
\hline & & & & & & None & 5 \\
\hline Total & 23 & & 23 & & 23 & & 23 \\
\hline
\end{tabular}

*Note: One article has two kinds of sample groups

\section{The Adopted Theoretical Frameworks and Dimensions in The Articles}

Table 5 informs those theoretical frameworks are in the sundry casing. However, there were many articles pointed from Autonomy Learning Taxonomy. However, some articles combining the frameworks with the others such as ZPD, Socio-Constructivist, Holistic, Cognitive, Self-Directive, Self-Determination, Learning Adaptability, Dual Coding Theory, Generative Theory of Multimedia Learning, Socio-Cultural Theory, Critical Reflection Theory, Correlation Theory Emotional Intelligence, Transformative Learning Theory, Activity Theory, Social Learning Theory, Teacher Belief \& Practice Theory, Exploratory Theory, Autonomous Readiness Theory, Integrative ICT with Autonomy Learning Theory, and Perceptions \& Perspectives Theory. On the other sides, the applied dimension in analytical frameworks emerges in the various pathways. Nonetheless, some articles are in the line of autonomy learning dimension. Nevertheless, the others were in the dimension of analytical frameworks in cognitive, social, cultural, pedagogical, psychological, comparison, correlation, perception, relation, communication, challenges, and constraints.

Table 5. The Adopted Theoretical Frameworks and Dimensions in The Articles

\begin{tabular}{ll}
\hline \multicolumn{1}{c}{ Theoretical Frameworks } & \multicolumn{1}{c}{ Dimension in Analytical Framework } \\
\hline $\begin{array}{l}\text { Zone of Proximal Development (ZPD) } \\
\text { \& Autonomy learning taxonomy }\end{array}$ & Metacognitive Strategies; Learners' Beliefs; Reflection; The Social Dimension \\
\hline Taxonomy of Dimensions of Autonomy & The Situational; The Behavioral; The Psychological \\
\hline $\begin{array}{l}\text { Socio-Constructivist Perspective } \\
\text { Autonomy learning taxonomy }\end{array}$ & $\begin{array}{l}\text { Reflective practice; Teacher/Student Backgrounds; Mismatch Between Teacher \& Student Expectations; } \\
\text { Limited Teacher Autonomy; Spoon-Feeding Tendencies of Teachers; Large Classes }\end{array}$ \\
\hline Holistic View of Teacher Cognition & Autonomy Freedom; Reflective Pedagogical Practice; Improvement Area \\
\hline $\begin{array}{l}\text { Association of Autonomy Learning with } \\
\text { self-directed learning and goal } \\
\text { commitment }\end{array}$ & Personal; Professional; Social Cultural; Historical Contexts \\
\hline Autonomy learning taxonomy & \\
\hline
\end{tabular}




\begin{tabular}{|c|c|}
\hline $\begin{array}{l}\text { Self-Determination Theory Perspective } \\
\text { \& Autonomy Support }\end{array}$ & $\begin{array}{l}\text { Willingness to communicate; Autonomy support; Perceived communicative competence; Language } \\
\text { mindsets }\end{array}$ \\
\hline Learning Adaptability & Learning Concept; Learning Environment; Learning Style \\
\hline Autonomy learning taxonomy & Socio-Cultural; Intercultural; Professional; Occupational; Institutional Forces \\
\hline $\begin{array}{l}\text { Dual Coding Theory; Generative Theory } \\
\text { of Multimedia Learning; Socio-Cultural } \\
\text { Theory }\end{array}$ & Teacher-Centered Comparison; Individual \& Pair-Work Comparison; Effect Virtual Environment \\
\hline Critical Reflection Theory & Learner Motivation; Learner Autonomy; Teacher Psychology; Pedagogical Considerations \\
\hline Critical Reflection Theory & Learners' Technology-Mediated Autonomous; Formal Contexts; Informal Contexts \\
\hline $\begin{array}{l}\text { Correlation Theory Emotional } \\
\text { Intelligence \& Learner Autonomy }\end{array}$ & Emotional Intelligence; Learner Autonomy \\
\hline $\begin{array}{l}\text { Social Constructivist Framework; } \\
\text { Transformative Learning Theory }\end{array}$ & Teacher's Perspectives of AL; AL Strategies; The Extent of LA \\
\hline Activity Theory & $\begin{array}{l}\text { Subject-Tool-Object; Subject-Division of Labors-Object; Subject-Community-Object; Subject-Rule- } \\
\text { Object }\end{array}$ \\
\hline Social Learning Theory & Early Childhood Multilingualism; Age, Gender, And Education Level \\
\hline $\begin{array}{l}\text { Self-Determination Theory and } \\
\text { Language Learner Autonomy } \\
\text { Taxonomy; Critical Reflection Theory }\end{array}$ & Language Learner Autonomy Perspective; Self-Determination Perspective; Self-Regulation Perspective \\
\hline $\begin{array}{l}\text { Teacher Belief \& Practice Theory; } \\
\text { Autonomy learning taxonomy }\end{array}$ & Teacher belief and practice; experience and licensure; LA Challenges \\
\hline Exploratory Theory & $\begin{array}{l}\text { Initiative; Context; Role; Objectives; Conceptual Framework; Strategies; Outcomes; Constraints; } \\
\text { Shortcomings }\end{array}$ \\
\hline $\begin{array}{l}\text { Autonomous Readiness Theory } \\
\text { Autonomy Learning Taxonomy }\end{array}$ & $\begin{array}{l}\text { Learners' Decision-Making Abilities \& Beliefs About Their Own and Teacher's Roles, Motivations, And } \\
\text { Metacognitive Strategies }\end{array}$ \\
\hline Critical Reflection Theory & $\begin{array}{l}\text { Two Early encounters with learner autonomy; The autonomy classroom as a learning community; } \\
\text { Language learner autonomy: three pedagogical principles and some theoretical reflections; The impact of } \\
\text { language learner autonomy; Future prospects }\end{array}$ \\
\hline $\begin{array}{l}\text { Integrative ICT with Autonomy } \\
\text { Learning Theory; Perceptions \& } \\
\text { Perspectives Theory }\end{array}$ & $\begin{array}{l}\text { Psychological Perspectives of Learner Autonomy; Technical Perspectives of Learner Autonomy; } \\
\text { Sociocultural Perspectives of Learner Autonomy; Political-Critical Perspectives of Learner Autonomy }\end{array}$ \\
\hline
\end{tabular}

In this study, SSCI-indexed 23 articles were published from 2016 to 2021 with the words "Autonomy Learning" in their title were examined by the systematic review method and the discussion about autonomy learning (AL). The systematic review findings contain 6 subheadings. The analysis of the distribution of 23 articles revealed that these articles were published in 15 journals. Innovation in Language Learning and Teaching, Language Teaching Research, and Cogent Education, which are the leading publications in autonomy learning, draw attention as the three journals most frequently publishing on the subject of AL. The finding by (Manzano Vázquez 3-9; Ahmadianzadeh et al. 6-11; Judy Shih 7-11; Wang and Ryan 8-23; Cirocki and Anam 11-19; Borg and Alshumaimeri 8-23; Fadaee et al. 8-22; Shabbani et al. 9-13) indicating that the three journals mentioned previously lead in the number of articles on AL that supports this conclusion as well. The applied research foci in the reviewed papers were not only in language education but also in various areas such as a computer (Peek 234); social science (Shabbani et al. 7); cultural (Wang and Ryan 5; Borg and Alshumaimeri 10; Tseng et al. 8; Tsai 8); engineering (Xu et al. 6); psychology (Stockwell and Reinders); and technology (Lai 8; Ding and Shen 2). It can be assumed that it demonstrates the multidisciplinary nature of the AL articles.

The changes of interests varying by year in the publication have shown from 2016 to 2018 with the topic of AL. There were such as related to teacher development (Manzano Vázquez 1-3), self-determination (Lou et al. 1-2), language learning locus control (Peek 230-34), and self-directed learning, particularly in the ESP community(Yang 1-2). At the beginning of 2019, have been raising demand on the varies issues such as a flipped classroom(Tsai 1-8), self-access centers (Şenbayrak et al. 1-2), in the nexus context formal and informal (Lai 1), technology, motivation and autonomy, and teacher psychology in language learning (Stockwell and Reinders), Massive Open Online Courses (MOOCs) (Ding and Shen 1), and teachers' beliefs and practices (Borg and Alshumaimeri 1-10). In the progress of 2021, the AL manuscript publications also have been rising in the points of language teaching styles (Fadaee et al. 1-3), multilateral interactive (Xu et al. 1-2), language mindsets, and communicative competence (Zarrinabadi et al. 1), selfdirection and goal commitment (Ozer and Yukselir 1), and collaborative learning logs (Judy Shih 1-2). In addition, the found articles covered in research articles with the number were 18 articles and five articles in the review articles.

The research foci and purposes resulted in the reviewed articles in diverse scopes. The foci seemed into three divisions. Firstly, the foci were integrating AL with technology explored by (Judy Shih 2; Xu et al. 6; Tseng et al. 8; Stockwell and Reinders 43; Lai 52; Peek 230; Tsai 2; Ding and Shen 2). Secondly, LA under the psychological approaches was delved by (Cirocki and Anam 3; Wang and Ryan 4; Ozer and Yukselir 2; Fadaee et al. 2; Zarrinabadi et al. 2; Shabbani et al. 2; Almusharraf 2; Yang 2; Lou et al. 3; 
Ahmadianzadeh et al. 2; Manzano Vázquez 2; Şenbayrak et al. 3; Little 5). Lastly, AL under the sociocultural approach was inquired by (Basri 2; Borg and Alshumaimeri 10; Tseng et al. 3; Tsai 20). At the same time, the purposes emerged in multiform points. Meanwhile, for the research purposes appeared in the various constructs. However, the most salient objectives are discussed in the construct of perceptions. Even though perceptions were dominant as the major, the discussion issues were diverse. For instance, Basri (1) aimed to investigate the influence factors in realizing autonomy and the support teachers provide and attempting to the learner's management. At the other points, Cirocki and Anam (8) inspected EFL practitioners' perceptions of autonomy to seven specific areas of pedagogical practice: instructional materials, course content, teaching methodology, assessment, classroom management, lesson planning, and school curriculum. On the other hand, Wang and Ryan (2) sought to probe the complexities of control shift in teachers' implementation of LA, their underlying rationales, and their understanding of the concept. Zarrinabadi (4) examined the relationship among autonomy support, language mindsets, communicative competence, and willingness to communicate in the EFL classroom. In the dissimilar issue, Shabbani (3) delved into the relationship between undergraduate students' emotional intelligence and their perceptions of learner's autonomy. In addition, Tsai (2) excavated how a flipped classroom can promote EFL learners' autonomous learning and how EFL students engage with the flipped learning environments to develop/modify their learning experiences to meet their goals.

Furthermore, the highly interesting countries in the AL study were China, Iran, and Taiwan. In other words, those countries much consider a lot in the AL process in language instruction and pay attention that $\mathrm{AL}$ is one of the prior aspects to overcome the constraints or challenges in achieving language target goals. The researcher from these countries also spliced AL with the integration of technology utilization in language education such as (Tseng et al. 21-25; Xu et al. 7-10; Ding and Shen 14-17; Lai 52-58; Yang 10-16; Tsai 20-24). On the other hand, Lai (55-56) argued that it is necessary to explore how technology can be designed and facilitated in the nexus of formal and informal settings to amplify AL. As Reinders (4) specified, the technology requires new skills for both learners and teachers, including fostering AL. Meanwhile, the researchers from Iran are more concerned in elaborating LA with a psychological domain such as AL with emotionally intelligent (Shabbani et al. 12-13), AL with language teaching style (Fadaee et al. 15-21), and AL with teacher's belief (Ahmadianzadeh et al. 9-12). Little (5) prominently shared three pedagogical principles in encouraging learner autonomy were: 1) use of the target language, 2) learner control, and 3) reflection. Benson (23) cited from Holec and Little that they conceptualized AL with the psychological approach, which emphasized planning, the selection of materials, monitoring learning progress and self-assessment, and learning management.

Thereunto, the revealed analysis in the applied research method the highest was the mixed method. The second line was quantitative, and in the third line, it was qualitative. Meanwhile, in a similar amount to qualitative research method was a review method. At the same time, the data collection tools were highly using a questionnaire. At the lower difference amount, it used an interview. Mainly for the quantitative method applied questionnaire or test such as (Fadaee et al. 7; Tseng et al. 9; Shabbani et al. 8; Yang 9; Peek 237; Şenbayrak et al. 6). In contrast, the qualitative method employed a questionnaire, interview, or observation (Judy Shih 5; Ding and Shen 7; Basri 4; Wang and Ryan 7; Almusharraf 6). Besides, in the mixed method applied questionnaire and interview namely (Cirocki and Anam 9; Ozer and Yukselir 7; Zarrinabadi et al. 4; Xu et al. 7; Borg and Alshumaimeri 16; Ahmadianzadeh et al. 5; Tsai 8). In addition, the obtained data collection tools were none particularly for the review articles, and they are such as (Stockwell and Reinders; Lai; Lou et al.; Manzano Vázquez; Little).

Additionally, the sample group mostly were the students since the related issues were enhancing learner autonomy. Still closely associated with the second attention to sample group was the teacher. Meanwhile, at the instruction level, the greatest concern to AL in the university level, and the next they were in the similar number tertiary and secondary. What's more, there was also in small number that is the primary level. Given the obtained analysis data, it can be assumed that in higher education, particularly in language education, AL is a prominent issue to be concerned about achieving language learning goals and aims. Despite this level, language learners must learn to generate reflection, self-evaluation, and metacognitive knowledge to strengthen their autonomy learning (Judy Shih 11). However, tertiary or secondary was necessary to cultivate AL in the other levels due to the restriction on recognizing and implementing AL (Cirocki and Anam 8; Borg and Alshumaimeri 30). Another one is related to instruction context that the most applied context in AL matter was blended, and the second position was online. It was due to the recent integration of massive technologies in education (Lai 53; Stockwell and Reinders 43). 
Besides, there were found in less number in an offline context. Continuously, there was also the unspecified size since the unexplained context in the reviewed articles. Lastly, the sample size involved mostly in the range of number 1-100, the second number was 101=200, the third number was 201-300 and 310-400, the final number was 701-800 and 801-900. In other additions, the "none" label indicated for sample group, instruction level, instruction context, and sample size, particularly for review article type.

Along with the theoretical frameworks, there were in the manifold rims. Nonetheless, the autonomy learning taxonomy was the base theoretical framework of the studies. Subsequently, it was elaborated under diverse approaches that linked with the dimension analytical frameworks. For instance, (Ding and Shen (8) began their paper by exploring the autonomy learning taxonomy with technology integration; afterward, they branched under the situational, behavioral, and psychological dimensions. They also outlined AL with metacognitive strategies for general and attention management, motivation control, and emotion control strategies. To sum up, carrying the AL topic may broadly discuss the various approaches, theoretical frameworks, and dimensions in analytical frameworks.

\section{Conclusions}

In the recent five years, the study of autonomy learning has consistently existed concerning language education's praxis. The systematic review in this study has explored the six components presented in the 23 reviewed articles. The obtained analysis revealed insights such as the change number of articles vary by year, foci and purposes, published article countries, utilized research methods, data collection tools, the occupied sample group and size, and the adopted theoretical frameworks and dimensions. The various novelties have been shown up for each of the analysis aspects in this study. However, the study meets limitations on the small number of reviewed articles and only, particularly in English education. Therefore, the further investigation of AL can be elaborated to other fields, domains, lenses, contexts, methods, theoretical frameworks, dimensions of analytical frameworks, and so forth. In addition, the implication of this study considerably can be useful for the freshmen or sophomore researchers to gain state of the art or novelty before conducting research or publishing papers. Besides, the elucidation of this study reported information about AL in the contemporary praxis of English Education.

\section{Acknowledgement}

The author received no financial support for the research, authorship, or publication of this article. The author would like to acknowledge the anonymous editors of this journal for their guidance and support for this manuscript.

\section{Notes on contributor}

Rina Husnaini Febriyanti is a full-time Lecturer in Universitas Indraprasta PGRI, Jakarta, Indonesia. She has been taking a Doctoral student at the Department of Applied Linguistics at Universitas Negeri Jakarta, Jakarta, Indonesia. Her domain interests are academic writing, CALL, English Language Teaching, EFL Instruction, and English Literature.

\section{ORCID iD}

Rina Husnaini Febriyanti (D) https://orcid.org/0000-0003-2215-3043

\section{References}

Ahmadianzadeh, Bijan, et al. "Exploring EFL Teachers' Beliefs about and Practices of Learner Autonomy across Experience and Licensure." Innovation in Language Learning and Teaching, vol. 14, no. 2, Taylor \& Francis, 2020, pp. 97-113, doi:10.1080/17501229.2018.1501694.

Almusharraf, Norah. "Teachers' Perspectives on Promoting Learner Autonomy for Vocabulary Development: A Case Study." Cogent Education, vol. 7, no. 1, Cogent, 2020, doi:10.1080/2331186X.2020.1823154.

Altinpulluk, Hakan, and Mehmet Kesim. "A Systematic Review of the Tendencies in the Use of Learning Management Systems." Turkish Online Journal of Distance Education, vol. 22, no. 3, 2021, pp. 114, doi:10.17718/tojde.961812.

Basri, Fatma. "Factors Influencing Learner Autonomy and Autonomy Support in a Faculty of Education." 
Teaching in Higher Education, vol. 0, no. 0, Taylor \& Francis, 2020, pp. 1-16, doi:10.1080/13562517.2020.1798921.

Benson, Phil. "Autonomy in Language Teaching and Learning." Language Teaching, vol. 40, no. 1, 2007, pp. 21-40, doi:10.1017/S0261444806003958.

Borg, Simon, and Yousif Alshumaimeri. "Language Learner Autonomy in a Tertiary Context: Teachers' Beliefs and Practices." Language Teaching Research, vol. 23, no. 1, 2019, pp. 9-38, doi: $10.1177 / 1362168817725759$.

Cirocki, Andrzej, and Syafi'ul Anam. "'How Much Freedom Do We Have?' The Perceived Autonomy of Secondary School EFL Teachers i n Indonesia." Language Teaching Research, 2021, pp. 1-26, doi:10.1177/13621688211007472.

Ding, Yan, and Huizhong Shen. "Delving into Learner Autonomy in an EFL MOOC in China: A Case Study." Computer Assisted Language Learning, vol. 0, no. 0, Taylor \& Francis Ltd., 2019, pp. 123, doi:10.1080/09588221.2019.1681464.

Fadaee, Elaheh, et al. "The Relationship between Autonomy, Second Language Teaching Styles, and Personality Traits: A Case Study of Iranian EFL Teachers." Cogent Education, vol. 8, no. 1, Cogent, 2021, doi:10.1080/2331186X.2021.1881203.

Judy Shih, Hui chia. "The Use of Individual and Collaborative Learning Logs and Their Impact on the Development of Learner Autonomy in the EFL Classroom in Taiwan." Innovation in Language Learning and Teaching, vol. 15, no. 3, Taylor \& Francis Ltd., 2021, pp. 195-209, doi:10.1080/17501229.2020.1737703.

Lai, Chun. "Technology and Learner Autonomy: An Argument in Favor of the Nexus of Formal and Informal Language Learning." Annual Review of Applied Linguistics, vol. 39, 2019, pp. 52-58, doi:10.1017/S0267190519000035.

Little, David. "Language Learner Autonomy: Rethinking Language Teaching." Language Teaching, Oxford/New York Pergamon Press, 2020, doi:10.1017/S0261444820000488.

Lou, Nigel Mantou, et al. "Complementary Perspectives on Autonomy in Self-Determination Theory and Language Learner Autonomy." TESOL Quarterly, vol. 52, no. 1, 2018, pp. 210-20, doi:10.1002/tesq.403.

Manzano Vázquez, Borja. "Teacher Development for Autonomy: An Exploratory Review of Language Teacher Education for Learner and Teacher Autonomy." Innovation in Language Learning and Teaching, vol. 12, no. 4, Taylor \& Francis, 2018, pp. 387-98, doi:10.1080/17501229.2016.1235171.

Moradi, Hamzeh. "An Exploration of Autonomy, Agency and Identity in EFL Contexts." English Today, vol. 3, no. 2020, 2020, pp. 1-3, doi:10.1017/s026607842000053x.

Ozer, Omer, and Ceyhun Yukselir. "“Am I Aware of My Roles as a Learner?' The Relationships of Learner Autonomy, Self-Direction and Goal Commitment to Academic Achievement among Turkish EFL Learners." Language Awareness, vol. 0, no. 0, Routledge, 2021, pp. 1-20, doi:10.1080/09658416.2021.1936539.

Peek, Ron. "Exploring Learner Autonomy: Language Learning Locus of Control in Multilinguals." International Journal of Multilingualism, vol. 13, no. 2, Taylor \& Francis, 2016, pp. 230-48, doi:10.1080/14790718.2015.1090991.

Reinders, Hayo. "Technology and Autonomy." The TESOL Encyclopedia of English Language Teaching, 2018, pp. 1-5, doi:10.1002/9781118784235.eelt0433.

Şenbayrak, Mürüvvet, et al. "An Exploratory Study on Turkish EFL Learners' Readiness for Autonomy and Attitudes toward Self-Access Centers." TESOL Journal, vol. 10, no. 2, 2019, doi:10.1002/tesj.401.

Shabbani, Mohammad Bagher, et al. "Undergraduate Students' Emotional Intelligence and Their Perceptions of Learner Autonomy: Interface between Social Science and English Language Students." Cogent Education, vol. 7, no. 1, Cogent, 2020, doi:10.1080/2331186X.2020.1850194.

Stockwell, Glenn, and Hayo Reinders. "Technology, Motivation and Autonomy, and Teacher Psychology in Language Learning: Exploring the Myths and Possibilities." Annual Review of Applied Linguistics, vol. 39, 2019, pp. 40-51, doi:10.1017/S0267190519000084.

Teng, Feng. "Autonomy, Agency, and Identity in Teaching and Learning English as a Foreign Language." Autonomy, Agency, and Identity in Teaching and Learning English as a Foreign Language, Springer Nature Singapore Pte Ltd., 2018, doi:10.1007/978-981-13-0728-7. 
Tsai, Yea Ru. "Promotion of Learner Autonomy within the Framework of a Flipped EFL Instructional Model: Perception and Perspectives." Computer Assisted Language Learning, vol. 0, no. 0, Routledge, 2019, pp. 1-32, doi:10.1080/09588221.2019.1650779.

Tseng, Wen Ta, et al. "Vocabulary Learning in Virtual Environments: Learner Autonomy and Collaboration." System, vol. 88, Elsevier Ltd, 2020, p. 102190, doi:10.1016/j.system.2019.102190.

Wang, $\mathrm{Na}$, et al. "Blended Learning for Chinese University EFL Learners: Learning Environment and Learner Perceptions." Computer Assisted Language Learning, vol. 34, no. 3, Routledge, 2021, pp. 297-323, doi:10.1080/09588221.2019.1607881.

Wang, Yi, and Jonathon Ryan. "The Complexity of Control Shift for Learner Autonomy: A Mixed-Method Case Study of Chinese EFL Teachers' Practice and Cognition." Language Teaching Research, 2020, doi:10.1177/1362168820957922.

$\mathrm{Xu}$, Shuyan, et al. "Multilateral Interactive Teaching Model for Improving Foreign Language Learners' Autonomous Learning Ability by Using Multimedia Network Technology." International Journal of Electrical Engineering Education, 2021, doi:10.1177/0020720920986077.

Yang, Yu Fen. "Self-Directed Learning to Develop Autonomy in an Online ESP Community." Interactive Learning Environments, vol. 24, no. 7, 2016, pp. 1629-46, doi:10.1080/10494820.2015.1041402.

Yang, Yu Fen, and Nai Cheng Kuo. "Blended Learning to Foster EFL College Students' Global Literacy." Computer Assisted Language Learning, vol. 0, no. 0, Routledge, 2021, pp. 1-22, doi:10.1080/09588221.2021.1900874.

Zarrinabadi, Nourollah, et al. "Autonomy Support Predicts Language Mindsets: Implications for Developing Communicative Competence and Willingness to Communicate in EFL Classrooms." Learning and Individual Differences, vol. 86, no. February, Elsevier Inc., 2021, p. 101981, doi:10.1016/j.lindif.2021.101981. 